\title{
The genetic-selection improvement of approaches to the study of the fruit cultures adaptation to the stresses of the spring and summer period*
}

\author{
Anna Kuznetsova ${ }^{1 * *}$, Irina Dragavtseva ${ }^{1}$, Sergey Shcheglov ${ }^{2}$, Anna Drygina ${ }^{1}$, \\ Vera Nikolenko ${ }^{3}$ \\ ${ }^{1}$ Federal State Budgetary Scientific Institution "North-Caucasus Federal Scientific Centre of \\ Horticulture, Viniculture, Winemaking", 39, 40-letie Pobedy Street, Krasnodar, Russia, 350901 \\ ${ }^{2}$ Federal State Budgetary Scientific Institution of Higher Education "Kuban State University", 149, \\ Stavropolskaya Street, Krasnodar, Russia, 350040 \\ ${ }^{3}$ V.I. Vernadsky Crimean Federal University, 4, Academician Vernadsky Avenue, Simferopol, \\ Republic of Crimea, 295007
}

\begin{abstract}
The happening global and local fluctuations of climate caused the changes in manifestation of the temperature stresses in the plants in terms of their strength and time of occurrence in vegetation period. The most regions of the south of Russia (especially in the plain territories) experienced warming of climate, and the temperature stresses began to appear more frequently in spring and in summer. With an aim to analyze the direction of change in temperature regime the structure and spectrums of variability in the mean-diurnal fluctuations of the maximum and minimum temperatures of air were studied for a long period (1950-2019) in the Kuban river horticulture zone of Krasnodar Territory. The defense and adaptive reactions of the sweet cherry varieties (in their drought resistance) to the change in external environment limits were brought to light. The yielding capacity of the genotypes of plants was studied from position of their response to the temperature stresses. The obtained results permitted to identify the varieties of sweet cherry, resistant to the stresses of the spring and summer period, when they are grown in conditions of the higher temperatures and considerable moisture deficit. The results of work will be helpful in control of the sweet cherry varieties productivity on the basis of knowledge on manifestation of the varieties' genetic peculiarities in their phenotype in the new climatic conditions.
\end{abstract}

\section{Introduction}

\footnotetext{
* The research was carried out with financial support of the Russian Foundation for Basic Research and Administration of Krasnodar Territory within a framework of scientific project nr.19-44-230023 p_a

** Corresponding author: anpalkuz@mail.ru
} 
The global changes in climate caused the new manifestations of strength, time of the temperature stresses occurrence and rain falls [1-4]. The perennial fruit cultures respond to these phenomena by unbalance of the phenological stages of development $[5,6]$. The degree of varieties adaptation to the limits of environment is associated with the level of their plasticity in the stages of development (in other words, with the level of the natural defense and adaptive functions) [7-11]. Consequently, studying the regularities of the fruit cultures varieties adaptation to the stress situations in the period of vegetation is a difficult task, permitting to improve the new approaches to selection process, when creating the varieties with increased adaptivity to the new limits of environment.

Should a plant possess a narrow range of tolerance to particular changing factor in the stages of development, it is just this factor which deserves consideration as a limiting one and must be taken into account when studying the variety's defense and adaptive functions to the change in conditions of external environment. Therefore the study of the plant's response to the action of environment lim-factors (first of all the temperature ones) is a difficult task, the solution of which in conditions of climatic changes will favour the increase in productivity of fruit cultures and their varieties, as well as will permit to advance in approaches, when choosing the parental forms in the process of selection. Besides, such work will permit to improve the accuracy of the predicted phenological reactions of fruit cultures to the further climatic changes and isolate the varieties, able to weaken the negative effects of stressors, appearing as the climate changes [12]. The isolation of adaptive forms requires the study not of all multiple-choice genotypeenvironment system, developing from plurality of the components $[13,14]$, but of the so called "essential variables", which have an effect to a greater extent on the character under study (in this case the resistance of genotypes to extreme conditions of the spring and summer period - the high temperature and lowered humidity conditions).

The purpose of work - identification of varieties with increased plasticity to the stressors of the spring and summer period in conditions of climatic fluctuation, using the methods of statistic analysis for the temperature readings of air for a multi-year period.

\section{Objects, methods and place of investigations}

The work was carried out on the basis of the functional selection and nursery science centre and laboratory of reproduction management in the fruit agrocoenoses and ecological systems on genetic collection of stone fruits of the Federal State Budgetary Scientific Institution "North-Caucasus Federal Scientific Centre of Horticulture, Viniculture, Winemaking". The analysis of temperature data was performed for the period of 1950-2019.

The objects of investigation are the culture of sweet cherry and its varieties. The laboratory conditions were to study the drought resistance in genotypes: clone Yaroslavna, Kavkazskaya uluchshennaya, Alaya, Volshebnitsa (breeded by the North-Caucasus Federal Scientific Centre of Horticulture, Viniculture, Winemaking), Romantika, Ultraranniaya, Bigarro Oratovskogo, Melitopolskaya ranniaya, low-growing clone Drogana zheltaya, Valeriy Chkalov, Ultraranniaya, Georgia, Summit Antipka grafted. The investigations comprised in field conditions the enlisted varieties, as well as Gendelfingenskaya, Sestrenka, Vasilisa, Melitopolskaya chernaya. The investigations involved 16 varieties 5 trees in each one.

The water-retaining capacity of the plants was determined from the lost mass of water in the leaves 2, 4 and 24 hours later The leaves of the plant under study (3-10 pieces, depending on the size), were taken in three replications in the periods of drought and high summer temperatures in June, July and August. The less is loss of water in a specimen under study, the higher is water-retaining capacity. The tissue water content of the tree 
leaves was determined from the difference between the initial wet weight and constant weight, achieved by desiccation in thermostat $\left(105^{\circ} \mathrm{C}\right)$.

To estimate the variability of the characters under study and to prove the right distribution the variance analysis was used, to construct correctly the homogeneous groups - the hierarchical cluster analysis according to the Ward and k-means method $[16,17]$. The statistical processing was carried out through the use of StatSoft Statistica 10.0 integrated system of statistic analysis and data treatment.

\section{Results of investigations}

It has been established that the daily mean temperatures of air within the range of $+20-24^{\circ} \mathrm{C}$ are considered to be optimal ones for the stone fruit cultures in summer period [18]. The elevation of daytime temperatures over $35^{\circ} \mathrm{C}$ inflicts the significant damages (leaf scalds). But much more significant problem is discomfort in the process of the flower buds differentiation, which slows down or comes to stop at the high summer temperatures in this period.

The study of the stress situations of summer period involved the analysis of variability structure and statistical processing of the daily mean, maximum and minimum air temperature values for 1950-2019 at the meteorological station of Krasnodar city. The variance analysis was undertaken for their quantitative evaluation in each of 12 months of the studied years. The net result is that a wide spectrum of the air temperature readings variability for the analyzed long period was revealed (Table 1).

Table 1. The variability of air temperature readings in 1950-2019 (city of Krasnodar)

\begin{tabular}{|c|c|c|c|c|}
\hline \multirow{2}{*}{ Month } & \multicolumn{4}{|c|}{ Share in total variance, \% } \\
\cline { 2 - 5 } & $\begin{array}{c}\text { Daily mean } \\
\text { air temperature }\end{array}$ & $\begin{array}{c}\text { Maximum } \\
\text { air temperature }\end{array}$ & $\begin{array}{c}\text { Minimum } \\
\text { air temperature }\end{array}$ & $\begin{array}{c}\text { Difference between } \\
\text { the maximum and } \\
\text { minimum air temperature }\end{array}$ \\
\hline 1 & 2 & 3 & 4 & 5 \\
\hline January & 25.0 & 24.1 & 27.0 & 6.2 \\
\hline February & 64.4 & 32.0 & 32.7 & 5.8 \\
\hline March & 26.9 & 21.5 & 28.1 & 4.9 \\
\hline April & 21.3 & 19.6 & 16.6 & 11.0 \\
\hline May & 21.7 & 18.8 & 16.5 & 7.1 \\
\hline June & 22.0 & 19.6 & 24.3 & 14.8 \\
\hline July & 28.8 & 25.4 & 27.9 & 14.7 \\
\hline August & 37.1 & 33.3 & 30.2 & 22.0 \\
\hline September & 43.4 & 43.7 & 33.4 & 10.4 \\
\hline October & 20.1 & 16.4 & 18.9 & 10.5 \\
\hline November & 20.1 & 18.2 & 20.6 & 7.2 \\
\hline December & 16.1 & 17.0 & 15.0 & \\
\hline
\end{tabular}

The regularities of the studied valuees variability were identified for a long period of investigations. It happened to be the largest one for the daily mean and maximum temperatures (February, September, August); minimum - February, March, July, August, September. The mostly significant difference between the maximum and minimum temperature of air was noted in June, July, August, September. 
The graphical analysis of all temperature readings under study from year to year proved the growth of the maximum temperatures (Fig. 1). The multiple investigations for a long period [7-14] confirm the detected tendency to have impact on the change in going through the phenological phases and, undoubtedly, on bud sets and differentiation of reproductive buds.

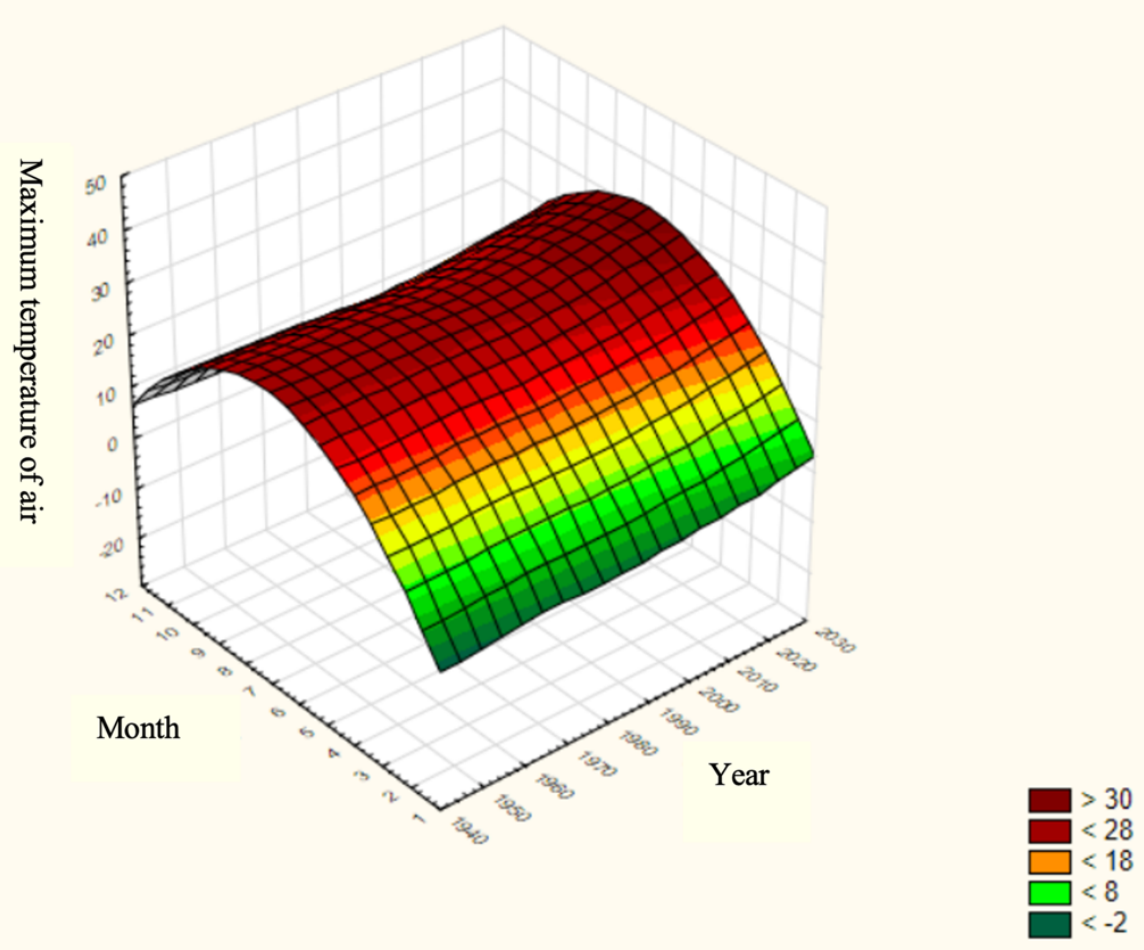

Fig. 1. Maximum temperature of air for 1950-2019 in the Kuban-tiver zone of horticulture

In an effort to group the years in terms of the forementioned temperature readings, their division is given with the use of dividual algorithm of k-means cluster analysis. The net result is that there were singled out three clusters, which comprised the years as follows: 1) $1950,1951,1954,1956,1958,1959,1963,1964,1969,1972,1973,1974,1976,1977$, 1978, 1980, 1982, 1983, 1984, 1986, 1987, 1988, 1991, 1992, 1993, 1997, 2004; 2) 1952, 1955, 1957, 1960, 1961, 1962, 1967, 1968, 1970, 1971, 1975, 1979, 1985, 1989, 1990, 1994, 1995, 1996, 1998, 2000, 2001, 2002, 2003, 2006, 2008, 2011; 3) 1966, 1981, 1999, 2005, 2007, 2009, 2010, 2012, 2013, 2014, 2015, 2016, 2017, 2018, 2019.

The variance analysis confirmed the differences between the clusters in daily mean, minimum and maximum temperatures of air. Included in the third cluster were the years with the notably increased temperature background - practically all the period.

The analysis of distribution of the temperature readings under study in the form of a year/month projection on the $3 \mathrm{D}$ graphs and surface plots give a display of important trend - the presence of cyclicity in the value of diurnal temperature variation (Fig. 2).

It has been established that the difference between the diurnal maximum and minimum temperatures of air is the largest one just in the summer months, and the decrease of it has a negative effect on the development of plants, especially the quality of their yield. This difference was made clear that it is greatly distinct throughout two periods of time: 1950-1981 and 1982-2013. The second period differs from the first one in the lesser 
variation of diurnal temperature by the effect of growth, primarily, of the nighttime temperatures. Beginning from 2014 there is a trend towards the greater difference of diurnal maximum and minimum temperature of air, in other words this parameter is subject to ciclicity in time with a 30-year interval, to support hypothesis of E.A. Brückner and A.I. Voieykov, put forward yet in the late 19th century. On evidence of our investigations the third cycle begins now (from 2014).

The validity of the chosen approach was confirmed by the data of 2018 and 2019 . The differentiation of the flower buds in 2018 proceeded in extremely unfavourable conditions both in the moisture conditions, when amount of precipitations was $11 \%$ of norm in June, $28 \%$ in August, and in temperature ones.

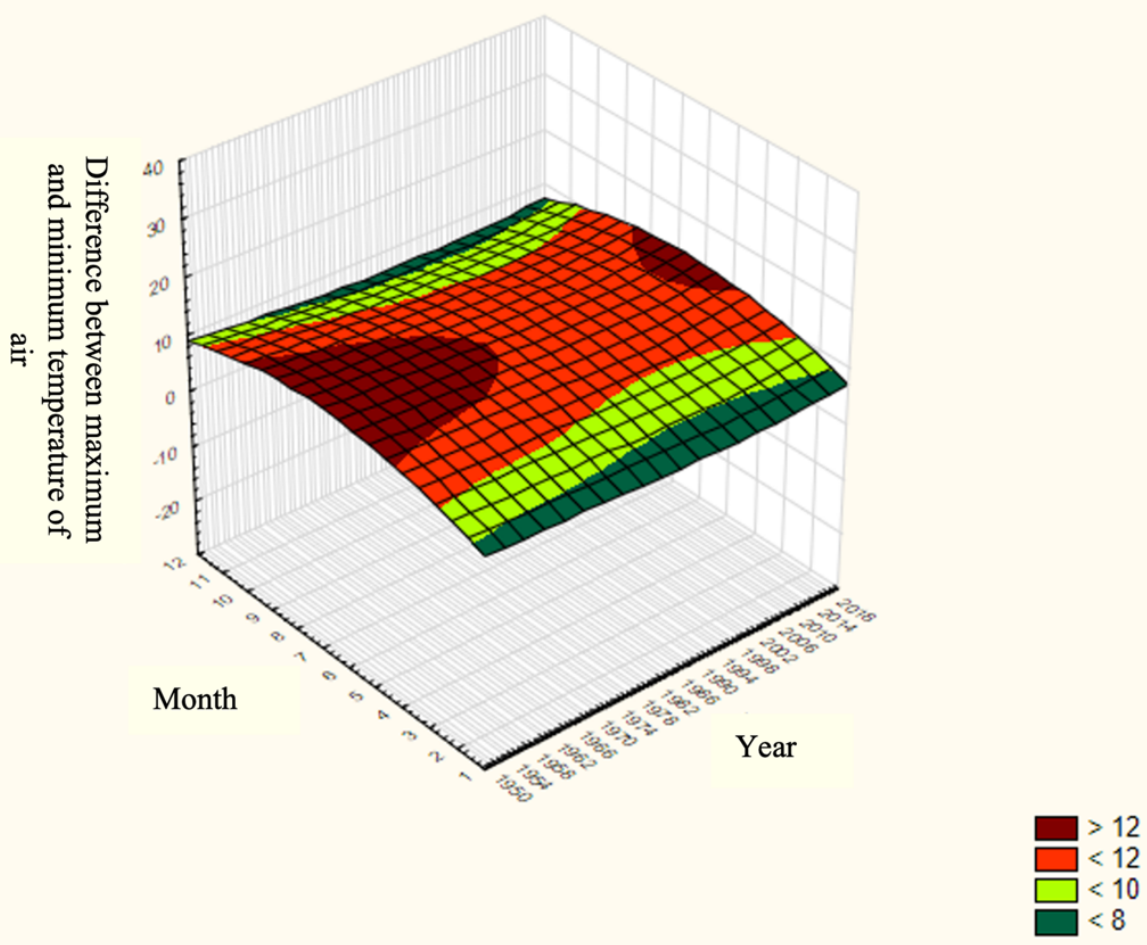

Fig. 2. The difference between diurnal minimum and maximum temperature of air for a multiyear period on SD-graph in Kuban river зоне of horticulture

The rise of mean air temperature in the vegetation period of 2018 was already $4.4^{\circ} \mathrm{C}$ in May with reference to the long-term average annual data and further the increase was equal every month to $0.8-5.4^{\circ} \mathrm{C}$, in such a case the maximum one was noted in June $-5.4^{\circ} \mathrm{C}$ and in late August $-4 \cdot 2^{\circ} \mathrm{C}$. All this had a negative effect on crop productivity of sweet cherry in collection and industrial gardens in 2019, its reduction was noted on average by $48-50 \%$ (Fig. 3). The varieties, noted for their high productivity both in 1950-1981 and in 2019 Frantsuzskaya chernaya (in the State register since 1959), Bigarro Oratovskogo (in the State register since 1951), Gedelfinghenskaya and Drogana zheltaya (in the State register since 1947) ranked among those, which produce the highest yield. Notwithstanding such unfavourable conditions, the enlisted varieties gave a display of good yielding capacity, that is evidenced by the high level of their defense and adaptive reactions to the stressors of summer period. 


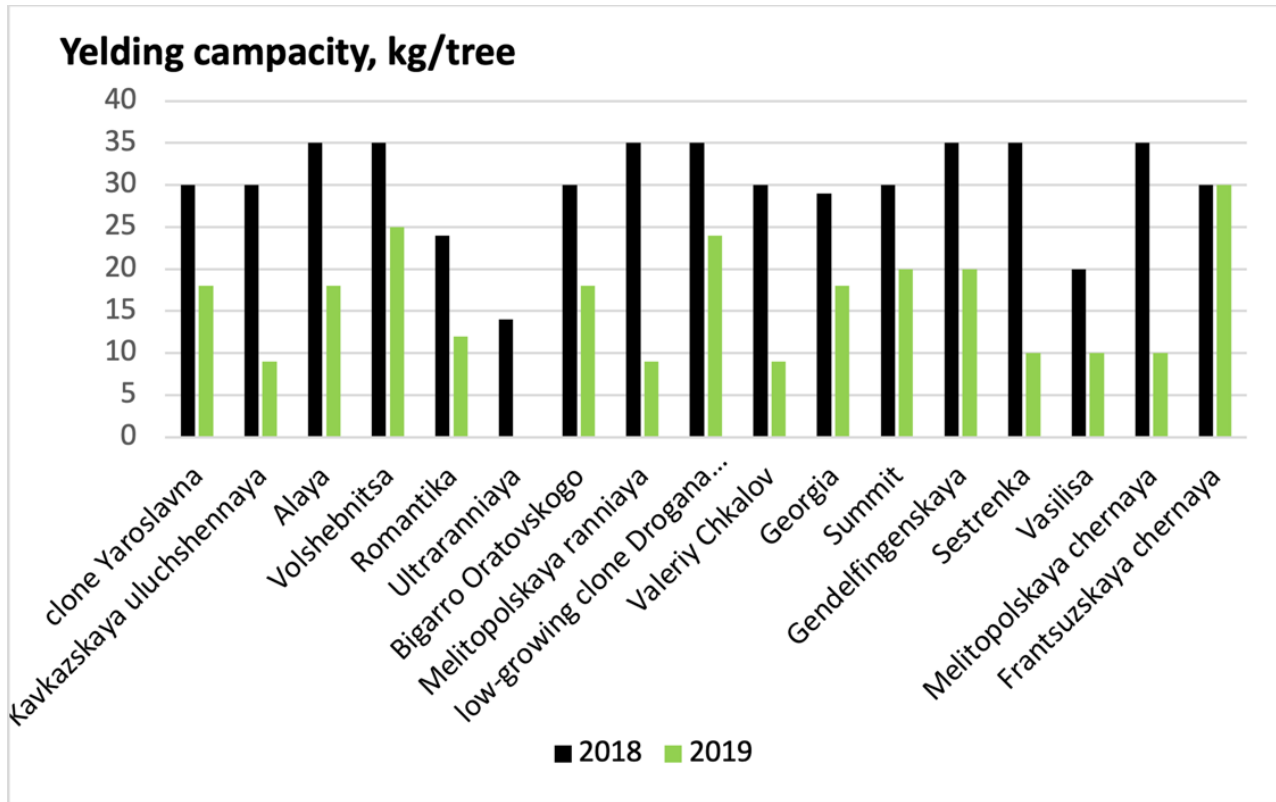

Fig. 3. Average yielding capacity of the sweet cherry varieties in collection plantings in conditions of 2018, 2019, Antipka srock

The obtained results permit to propose the new methodological approach to evaluation of the fruit cultures assortment in terms of yielding capacity on the basis of retrospective analysis of the difference between the diurnal maximum and minimum temperature of air in summer vegetation months and identify the varieties mostly adaptive to the changes in temperature regime at the most important stages of the fruit cultures development.

The genetic-statistical analysis of obtained data on water-retaining capacity of the leaf tissues also confirmed the high adaptivity of the isolated genotypes to the stresses of summer period. The varieties Frantsuzskaya chernaya, Bigarro Oratovskogo, low-growing clone Drogana zheltaya, as the division through the use of Ward, k-means and t-criterion methods was carried out, got verifiably into the cluster with the largest values of the factor under investigation, in other words with the least losses of water in the drought periods, as observations were made in June, July and August of 2019. The laboratory investigations resulted also is isolation of the varieties Alaya, clone variety Yaroslavna and Volshebnitsa (Fig. 4, 5) breeded by the North-Caucasus Federal Scientific Centre of Horticulture, Viniculture, Winemaking. Variety Gendelfingenskaya was not studied duting the laboratory investigations. 


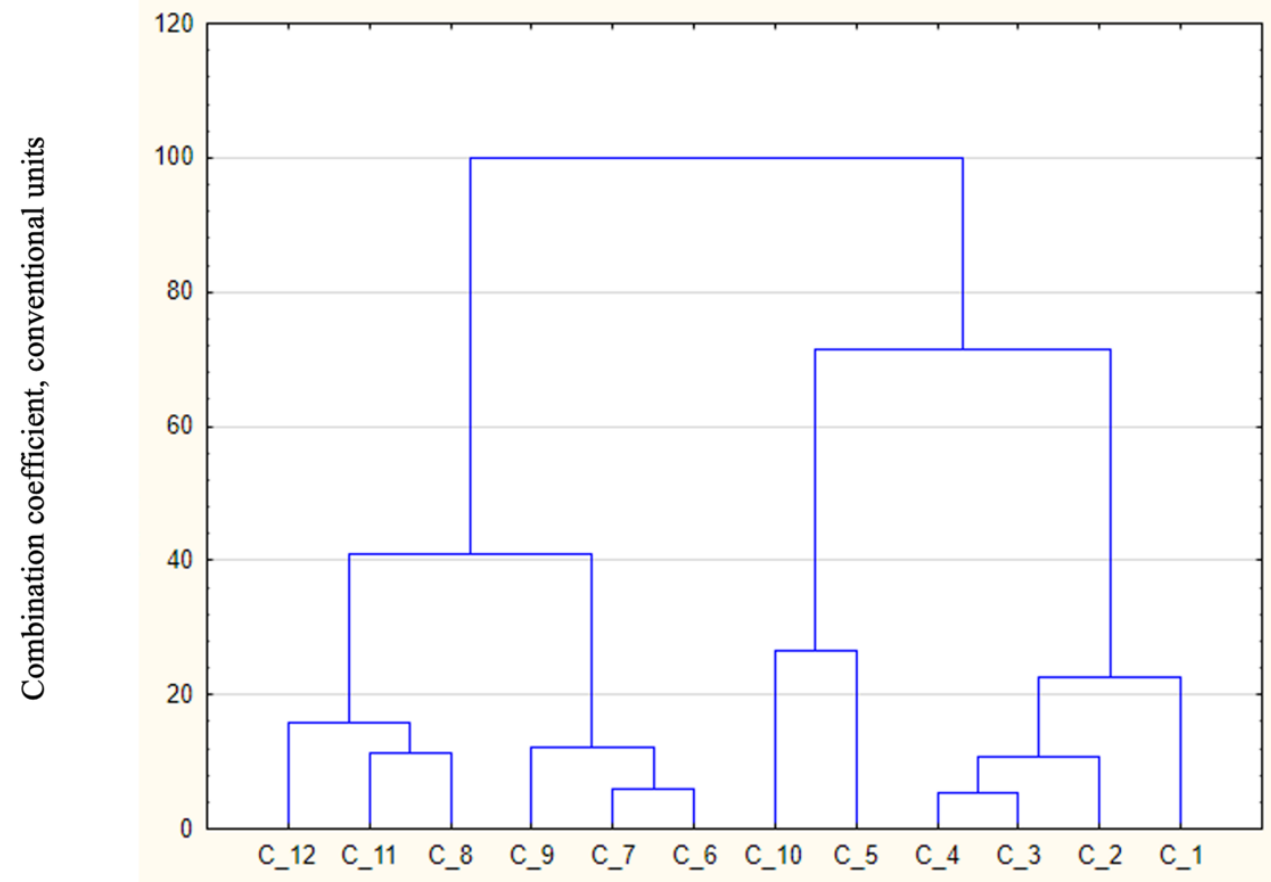

Fig. 4. The results of water-retaining capacity cluster analysis 2, 4, 24 hours later in the leaves of sweet cherry (June, 2019): Alaya (6), Frantsuzskaya chernaya (7), Bigarro Oratovskogo (8), low-growing clone Drogana zheltaya (11), clone Yaroslavna (9), Volshebnitsa (12)

Table 2 - The comparison of the water-retaining capacity mean values and water content from the different clusters when cutting 45 conventional units (June, 2019)

\begin{tabular}{|c|c|c|c|c|}
\hline Cluster & $\begin{array}{c}\text { Water-retaining } \\
\text { capacity } \\
\text { (2 hours) \% }\end{array}$ & $\begin{array}{c}\text { Water-retaining } \\
\text { capacity } \\
\text { (4 hours) } \%\end{array}$ & $\begin{array}{c}\text { Water-retaining } \\
\text { capacity } \\
(24 \text { hours }) \%\end{array}$ & $\begin{array}{c}\text { Water content } \\
\%\end{array}$ \\
\hline 1 & 15.4 & 41.20 & 68.4 & 80.2 \\
\hline 2 & 13.6 & 39.4 & 60.1 & 72.4 \\
\hline 3 & 11.4 & 37.1 & 50.9 & 76.7 \\
\hline
\end{tabular}

The climatic change with the temperature fluctuations of different periods is overlaid upon biopotential of the plants, at the cost of which the new variants of interactions are materialized in "genotype-environment" system. The identification of trends of the mutual interactions permit to improve the estimation of the degree of fruit cultures adaptation to the new temperature stresses of the spring and summer period.

\section{Conclusion}

1. The happening global and local fluctuations of climate caused the manifestation of the new temperature stresses, having negative effect on the state of plants and their productivity in the current and future years.

2. The retrospective analysis of the sweet cherry assortment in terms of yielding capacity in the years with the largest difference between the diurnal maximum and minimum air temperatures in summer months of vegetation may serve as a methodological 
approach to the fruit-bearing stability of the fruit cultures varieties in the new climatic conditions.

3. The trend in climatic changes direction and its influence on feedback response of the studied sweet cherry varieties was revealed.

4. At the level of increase in temperature readings, especially in summer period with manifestation of the long-lasting drought, there were isolated new varieties Alaya, clone Yaroslavna, Volshebnitsa, breeded by the North-Caucasus Federal Scientific Centre of Horticulture, Viniculture, Winemaking and well known ones - Frantsuzskaya chernaya, Gendelfingenskaya, low-growing clone Drogana zheltaya, Bigarro Oratovskogo, which may be used as the sources of high adaptivity to the stress situations of summer period in selection of sweet cherry.

The research was carried out with financial support of the Russian Foundation for Basic Research and Administration of Krasnodar Territory within a framework of scientific project nr.19-44-230023 p_a

\section{References}

1. F. M. Chmielewski, Phenology: An Integrative Environmental Science, 539-561 (2013). http://doi.org/10.1007/978-94-007-6925-0_29

2. Y. Ding, Z. Li, S. Peng. Int. J. Appl. Earth Obs., 92, 102179 (2020). https://doi.org/10.1016/j.jag.2020.102179

3. L. Busetto, R. Colombo, M. Migliavacca, E. Cremonese, M. Meroni, M. Galvagno, M. Rossini, C. Siniscalco, U. Morra Di Cella, E. Pari, Glob. Chang. Biol., 16 (9), 2504-2517 (2010). https://doi.org/10.1111/j.1365-2486.2010.02189.x

4. V. Pandey, A. K. Misra, S. B. Yadav, Water and energy security in the area of climate change, 7-12 (2017). https://www.researchgate.net/publication/323573924_ClimateAgriculture_Vulnerability_Assessment

5. K. M. Becklin, J. T. Anderson, L. M. Gerhart, S. M. Wadgymar, C. A. Wessinger, J. K. Ward, Plant Physiol., 172, 635-649 (2016). https://doi.org/10.1104/pp.16.00793

6. J. L. Hatfield, J. H. Prueger, Weather Clim. Extremes, 10(A), 4-10 (2015) https://doi.org/10.1016/j.wace.2015.08.001

7. E. Ivits, M. Cherlet, G. Tóth, S. Sommer, W. Mehl, J. Vogt, F. Micale, Glob. Planet. Chang., 88-89, 85-97 (2012). https://doi.org/10.1016/j.gloplacha.2012.03.010

8. O. Gordo, J. José Sanz, Glob. Change Biol., 16(3), 1082-1106 (2010). https://doi.org/10.1111/j.1365-2486.2009.02084.x

9. N. I. Nenko, G. K. Kiseleva, H. V. Ulyanovskaya, Agriculture \& Food. 3, 202-208 (2015). https://www.scientific-publications.net/en/article/1000672/

10. S. Jiménez, M. Fattahi, K. Bedis, S. Nasrolahpour-moghadam, J. J. Irigoyen, Y. Gogorcena, Front. Plant Sci., 11, 43 (2020). DOI: https://doi.org/ 10.3389/fpls.2020.00043

11. P. Q. Craufurd, V. Vadez, K. Jagadish, V. Prasad. Agric. For. Meteorol. 170, 8-18 (2013). https://doi.org/10.1016/j.agrformet.2011.09.003

12. A.B. Nicotra, O.K. Atkin, S.P. Bonser, A.M. Davidson, E.J. Finnegan, U. Mathesius, P. Poot, M.D. Purugganan, C.L. Richards, F. Valladares, M. van Kleunen, Trends Plant Sci., 15(12), 684-692 (2010). https://doi.org/10.1016/j.tplants.2010.09.008

13. A. P. Kuznetsova, A. I. Drygina, D. A. Madzhar, S. I. Gridnev, M. S. Lenivtseva, 56, 157-170 (2019). http://doi.org/10.30679/2219-5335-2019-2-56-157-170

14. V. A. Dragavtsev, I. A. Dragavtseva, I. L. Efimova, A. P. Kuznetsova, A. S. Morenets,

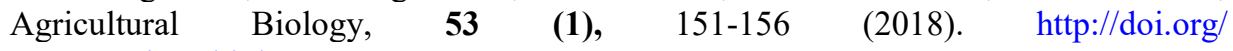
10.15389/agrobiology.2018.1.151eng 
15. M. S. Lenivtseva, E. E. Radchenko, A. P. Kuznetsova, Agricultural Biology, Fruit growing and viticulture of South Russia, 52(5), 895-904 (2017). http://doi.org/10.15389/agrobiology.2017.5.895eng

16. D. Eszergár-Kiss, B. Caesar. Transp. Res. Procedia. 22, 25-34 (2017). https://doi.org/ 10.1016/j.trpro.2017.03.004

17. M. M. Fard, T. Thonet, E. Gaussier, Pattern Recognit. Lett., (to be published) 138, 185-192 (2020). https://doi.org/10.1016/j.patrec.2020.07.028

18. I. A. Dragavtseva, V. A. Dragavtsev, I. L. Yefimova, A. P. Kuznetsova, A. V. Klyukina, IJAST, 29 (7), 1971-1983 (2020). https://sersc.org/journals/index.php/IJAST/article/ view/17127 